\title{
Differential shell strength of Cepaea nemoralis colour morphs-implications for their anti-predator defence
}

\author{
Zuzanna M. Rosin • Jarosław Kobak • Andrzej Lesicki • \\ Piotr Tryjanowski
}

Received: 5 February 2013 /Revised: 9 July 2013 / Accepted: 12 July 2013 /Published online: 7 August 2013

(C) The Author(s) 2013. This article is published with open access at Springerlink.com

\begin{abstract}
One of the most spectacular evolutionary forces is predation, evidenced to stimulate polymorphism in many prey species. Shell colour polymorphism of the land snail Cepaea nemoralis is a well-known model in evolutionary research. Nevertheless, the knowledge on the ecological causes driving its evolution remains incomplete and proximal factors shaping predatory pressure on $C$. nemoralis morphs are unknown. We evaluated shell crushing resistance and thickness, constituting crucial snail anti-predator defences in two shell areas (the apex and labium) of eight $C$. nemoralis morphotypes differing in shell colour and banding pattern. A GLM showed a significant effect of shell colour, banding pattern and shell thickness on shell strength. Pink shells were stronger than yellow ones, and banded forms had stronger shells than unbanded snails. The labium (usually attacked by mice) was generally thicker and more resistant than the apex (usually crushed by birds). Thicker shells were more resistant to crushing, and the rate of shell strength increase per unit of shell thickness was greater in pink and banded individuals compared to yellow and unbanded ones. Yellow and unbanded morphs have been found to be preferred by mice in the previous studies, which suggests that
\end{abstract}

Communicated by: Sven Thatje

Z. M. Rosin $(\bowtie) \cdot$ A. Lesicki

Department of Cell Biology, Institute of Experimental Biology, Adam Mickiewicz University, Umultowska 89, 61-614 Poznań, Poland

e-mail: zuziarosin@o2.pl

J. Kobak

Department of Invertebrate Zoology, Faculty of Biology and Environmental Protection, Nicolaus Copernicus University, Lwowska 1, 87-100 Toruń, Poland

P. Tryjanowski

Institute of Zoology, Poznań University of Life Sciences, Wojska

Polskiego 71C, 60-625 Poznań, Poland shell strength may be an important trait used in prey selection by these shell-crushing predators. The differences in potential anti-predator defences among snail morphs, found in the present study, justify future research on direct effect of $C$. nemoralis morphs shell strength on predator selectivity.

Keywords Polymorphism - Shell crushing resistance . Labium $\cdot$ Banding type

\section{Introduction}

The importance of differential predation pressure has been well evidenced for the evolution and maintenance of polymorphism in many prey species, including mammals (Hoekstra et al. 2004), reptiles (Rosenblum et al. 2004), fish (Svänback and Eklöv 2011), insects (Ruxton et al. 2004; Rowland et al. 2008), crustaceans (Merilaita 2001; Hargeby et al. 2004) and gastropods (Johannesson and Ekendahl 2002). Therefore, morphologically variable species are excellent objects of studies on causes and effects of selective predatory pressure (Punzalan et al. 2005). Surprisingly, its role in the polymorphism of the well-studied the brownlipped grove snail Cepaea nemoralis (L.) is still uncertain.

Populations of $C$. nemoralis exhibit genetic variability in shell colour (mainly yellow, pink or brown) and banding pattern (zero, one, three or five dark bands sometimes joined together) (Richards and Murray 1975). The knowledge on the ecological causes of maintenance of this polymorphic coloration is still incomplete despite over 100 years of studies (Cook 1998, 2005; Ożgo 2008; Cameron and Cook 2012; Pokryszko et al. 2012). Many factors may affect spatiotemporal variability in Cepaea shell colour, including genetic drift, migration, climatic selection, habitat heterogeneity and landscape structure (e.g. Jones 1974; Hutchison and Templeton 1999; Cameron and Pokryszko 2008; Le Mitouard et al. 2010; Silvertown et al. 2011; Ożgo 2012). Selective predation by birds has long been 
suggested as one of the main forces maintaining polymorphism in Cepaea shell coloration (e.g. Cain and Sheppard 1954; Allen 2004; Cook 2005; Punzalan et al. 2005; Rosin et al. 2011), but the exact mechanism behind this process remains uncertain.

Two main hypotheses have been formulated in attempts to explain differential predator selectivity toward Cepaea morphs, selection for crypsis (Cain and Sheppard 1950, 1954) and frequency-dependent selection (Clarke 1962). Cain and Sheppard $(1950,1954)$ showed that avian predation on yellow Cepaea was highest in the early spring and gradually decreased as the season advanced and vegetation developed. This pattern was explained by changes in habitat conspicuousness for the yellow morph (Cain and Sheppard 1950, 1954). On the other hand, Cook (1986) found no evidence that avian preference toward particular Cepaea morphs depended on background colour. Studies on the role of apostatic selection have provided evidence both in support of and against this hypothesis (Clarke 1962, 1969; Allen and Clarke 1968; Allen and Weale 2005). The latest study by Rosin et al. (2011) showed that mice prey most heavily on yellow unbanded and one-banded C. nemoralis morphs, whereas birds prefer colours other than brown.

In the field, C. nemoralis may be exposed to many predators, mainly birds, such as the blackbird Turdus merula L. and the song thrush Turdus philomelos C. L. Brehm, as well as mammals, such as mouse Apodemus sp., differing in their sensory capabilities, foraging behaviour and manner of prey handling (Morris 1954; Wolda 1963; Allen 2004). Thus, these predators may provoke different defence strategies. Crypsis, mucus production and the shell itself are the most important snail defences (Allen 2004). Whereas, the conspicuousness of $C$. nemoralis shell colouration for visual predators has been deeply studied (e.g. Sheppard 1951; Allen and Weale 2005; Surmacki et al. 2013), other features of its shell, such as thickness and strength, which are potentially important for predators are very poorly recognised (Jordaens et al. 2006). Moreover, there is some evidence that the dark pigmentation may strengthen the shell (Cook and Kenyon 1993). Therefore, it would be important to understand not only the effects of shell colour on crypsis but also on a direct resistance to predation.

According to optimal foraging theory, the shell thickness of optimum prey individuals should be small enough to allow their breaking, but at the same time the body size should be large enough to provide a worthwhile portion of food (Stephen and Krebs 1986; Quensen and Woodruff 1997; Norris and Johnstone 1998; Reed and Janzen 1999). Since some predators (e.g. mice) may operate by trial and error when searching for food (Rosin and Tryjanowski personal observations), it is possible that snails with more resistant shells show higher survival when exposed to predation, which has not been considered in studies on predation on Cepaea so far (e.g. Cain and Sheppard 1954; Clarke
1962). It has been shown that crushing predators impose a selective pressure on external skeletons of mussels (e.g. Durell et al. 1984; Krist 2002; Smallegange and van der Meer 2003), freshwater gastropods (e.g. Kitching and Lockwood 1974; Lewis and Magnuson 1999) and crustaceans (Huelsken 2011). However, only few papers have dealt with this problem in land snails (Gittenberger 1996; Quensen and Woodruff 1997; Moreno-Rueda 2009).

The aim of the present study was to evaluate shell crushing resistance among various $C$. nemoralis morphs. We hypothesised that shell resistance to breakage could be associated with its colour and banding type, as these features affect the susceptibility of snails to predators (e.g. Cain and Sheppard 1954; Rosin et al. 2011).

\section{Material and methods}

\section{Study species}

The genetic basis of the brown-lipped grove snail Cepaea nemoralis (L.) variability has been well investigated. Genes determining shell colour as well as band appearance and colour form a supergene. Genes determining shell and band colour are located close together. Brown colour is dominant over pink and yellow, whereas pink is dominant over yellow. Alleles responsible for the number of bands are located in other unlinked loci. The gene determining the lack of bands is dominant and epistatic to alleles responsible for band appearance (Lamotte 1954; Cain et al. 1968; Murray 1975; Jones et al. 1977). The distribution of morphs is sympatric and almost every population is variable in shell colour and banding pattern (Jones et al. 1977).

\section{Study area}

Individuals of Cepaea nemoralis (L.) were collected between April and July 2009 from a population located near the city of Poznań, Wielkopolska, Poland $\left(52^{\circ} 26^{\prime} \mathrm{N}, 16^{\circ} 52^{\prime}\right.$ E). The sampling site covered $400 \mathrm{~m}^{2}$, which is the estimated size of one panmictic unit in C. nemoralis (Lamotte 1951). Specimens were collected from a diversified site where vegetation has been spontaneously developing for over 50 years. Our study area was dominated by open habitats that were composed mainly of grasses (about $40 \%$ of the site area) and psammophilic vegetation (about $30 \%$ of the site area) with dwarf everlast [Helichrysum arenarium (L.)]. Dark shaded habitats (ca. $30 \%$ of the area) were composed of shrubs, including blackthorn (Prunus spinosa L.) and trees such as black locust (Robinia pseudoacacia L., Fabaceae) and hedge maple (Acer campestre L.). As the collection of snails was random across the sampling site and the percentages of particular morphs occurring in various microhabitats within 
the site were similar (chi-square test for the distribution of shell colours: $\chi_{1}^{2}=0.02, P=0.897$ and banding types: $\chi_{3}^{2}=1.21, P=0.752$ ), it is unlikely that any differences among the morphs were caused by microhabitat-related environmental factors. Both avian (T. merula) and mammalian predators (Apodemus sp.) were observed in the study plot.

Data collection

Visual searching for adult snails was done by an experienced human observer along transects with haphazard sampling. Altogether, 260 adult specimens of $C$. nemoralis were collected. Snails with the evidence of prior predation-with damaged shells and/or scars on the shell were excluded during collection. Shell colour (yellow, pink or brown; Cain and Currey 1963) and the number of bands were recorded. Four types of shell banding were distinguished: (1) midbanded (banding type 00300, according to Cain and Sheppard 1950, 1954; Fig. 1), (2) three-banded (00345), (3) five-banded (12345) or (4) unbanded (00000). In our study area, all morph types but brown ones were present, resulting in eight different morphs altogether.

\section{Handling of snails and basic measurements}

Collected snails were kept in plastic, aerated boxes at $22{ }^{\circ} \mathrm{C}$ and humidity of 80-90\% without food (to empty their alimentary canals) for $24 \mathrm{~h}$ after the capture. Next, snails were weighed with a scale (to the nearest $0.01 \mathrm{~g}$ ), individually marked and frozen at $-20{ }^{\circ} \mathrm{C}$ for 10 days. Then, mortified snails were defrosted at $22^{\circ} \mathrm{C}$ for $5-7 \mathrm{~h}$. Shell width and

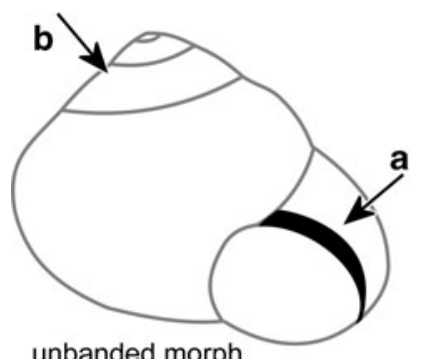

unbanded morph

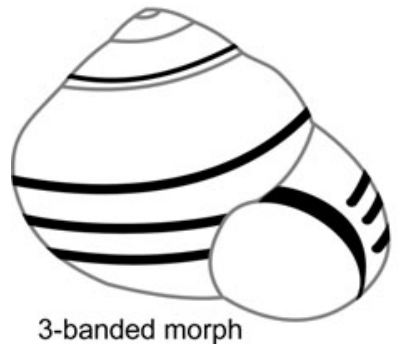

Fig. 1 Scheme of banding types of $C$. nemoralis morphs. Shell areas subjected to strength measurements are shown on the unbanded morph: $A$ labium (usually attacked by mice) and $B$ left side of the second whorl (usually broken by birds) columella height were measured using callipers $(0.01 \mathrm{~mm}$ accuracy) according to standard methods (Wiktor 2004). Immediately after defrosting, shell strength was measured (with soft tissues present inside the shells) as shell resistance to breakage. The measurements were done with the use of dynamometer FG-5000A (Lutron Electronic Enterprise Co. Ltd, Taipei, Taiwan) to the nearest 0.01 N. A sharp conical tip was mounted on the force gauge, and the device was pushed onto the shell of a stabilised individual until the shell surface broke (Jordaens et al. 2006). After extraction of snail soft tissues, shell wet mass (all fragments) was measured with a scale (to the nearest $0.01 \mathrm{~g}$ ). Because avian and mammalian predators differ in their manner of breaking and extracting shell contents (Morris 1954; Wolda 1963; Fig. 2), shell strength was measured in two different shell areas (Fig. 1): (1) near the shell apex, on the left side of the second whorl ("avian type") and (2) near the labium, ca. $2 \mathrm{~mm}$ above the shell aperture ("mouse type"). Snails from each morphological type were randomly assigned to one of the breakage types (at the apex or labium). Moreover, three calliper measurements (to the nearest $0.01 \mathrm{~mm}$ ) were taken in different positions around the breakage and the mean was calculated as an estimate of shell thickness (Jordaens et al. 2006). As a result, there were two groups of individuals within each morph: (1) those with shell resistance and thickness measured near the apex and (2) those with both measurements taken above the labium.

\section{Statistical analyses}

To compare shell parameters (such as width, mass and columella height) among various morphs, we used two-way ANOVAs followed by Tukey post hoc tests as a post hoc procedure, with shell colour and banding type as factors. Differences in shell thickness were analysed with shell area (apex or labium) as the third factor by three-way ANOVA. Spearman correlations were used to check whether the abovementioned shell features were correlated with one another and with shell strength. A general linear model was used to test the effect of shell colour, banding pattern, shell area (grouping variables), shell thickness (covariate) and their interactions on shell strength (dependent variable). Sequential Bonferroni-corrected Fisher's LSD tests were used
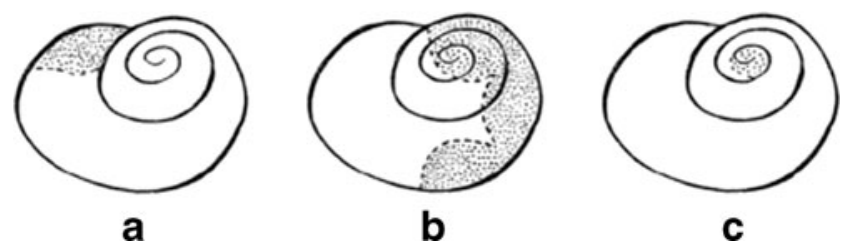

Fig. 2 a-c Shells of terrestrial snails with typical areas (shaded) usually damaged by mice (a) or birds (b and $\mathbf{c}$ ). Occasionally, a shell may show a combination of both types of damage and thus may have been damaged by both predators (after Rosin et al. 2011) 
as a post hoc procedure for significant effects of the grouping variables. In the cases of significant interactions of the covariate with the grouping variables, the regression slopes for particular levels of the grouping variables were compared with one another using the procedure described by Sokal and Rohlf(1995). All calculations were carried out by SPSS 19.0 software.

\section{Results}

Snail shell traits and their relations

Shell width and thickness were related to banding pattern, with three-banded shells being narrower and unbanded shells thinner than the other morphs (Tables 1 and 2). Moreover, shells were thicker near the labium than at the apex (Tables 1 and 2). Columella height (mean $\pm \mathrm{SE}, 12.14 \pm 0.04 \mathrm{~mm}$ ) and shell mass $(0.57 \pm 0.01 \mathrm{~g})$ (Table 1$)$ did not differ significantly among the studied morphs (Table 2).

Shell strength was positively correlated with shell thickness and mass (Table 3). That is why we selected shell thickness as a covariate for the general linear model to test the effects of snail morphs on shell resistance. Since shell thickness and mass were strongly correlated with each other, there was no need to include both variables into the model. Moreover, columella height was positively related to shell thickness and strength at the apex but not at the labium (Table 3).

\section{Shell strength}

Shell strength ranged from 8.1 to $55.00 \mathrm{~N}$, with the mean ( \pm SE) being $22.68 \pm 0.85 \mathrm{~N}$ and $26.75 \pm 0.91 \mathrm{~N}$ for the apex and labium, respectively (Fig. 3).
Shells of pink morphs were generally stronger than those of yellow snails (Fig. 3), as shown by a significant colour effect in the general linear model (Table 4). The effect of banding type on shell strength depended on shell area (a significant banding $\times$ shell area interaction in the model, Table 4). The area near the apex was strongest in threebanded morphs and weakest in five-banded individuals (Fig. 3). On the other hand, the labium was least resistant to breakage in unbanded snails, whereas its strength did not differ among the other morphs (Fig. 3). The labium was generally more resistant than the apex, though a significant difference between both locations on the shell surface was only found for five-banded morphs (Fig. 3).

Shell resistance was strongly positively related to its thickness, but this relationship varied between shell colours and banding types, as shown by significant colour $\times$ thickness and banding $\times$ thickness interactions (Table 4). Shell strength of pink snails increased with the increment of shell thickness faster than that of yellow individuals, as indicated by a significant difference between the regression slopes (Fig. 4a). Moreover, the gain in shell strength with the increase in its thickness was greater in banded morphs, with a significant difference between the slopes for three-banded and unbanded individuals (Fig. 4b).

\section{Discussion}

We have shown that colour morphs of $C$. nemoralis significantly differ in shell strength as well as in the magnitude of strength gain per unit of increment of thickness. Shell strength also differed between shell areas usually attacked by birds and mice. Thus, shell strength may be important in determining predator selection among morphs.
Table 1 Mean $( \pm \mathrm{SE})$ values of columella height, shell width, thickness and mass of $C$. nemoralis morphs

Sample sizes of each morph category are presented in Fig. 3

\begin{tabular}{|c|c|c|c|c|c|}
\hline \multirow[t]{2}{*}{ Morph } & \multirow{2}{*}{$\begin{array}{l}\text { Columella } \\
\text { height }[\mathrm{mm}]\end{array}$} & \multirow[t]{2}{*}{ Shell width $[\mathrm{mm}]$} & \multirow[t]{2}{*}{ Shell mass [g] } & \multicolumn{2}{|c|}{ Shell thickness $[\mathrm{mm}]$} \\
\hline & & & & $\begin{array}{l}\text { Broken at } \\
\text { apex }\end{array}$ & $\begin{array}{l}\text { Broken at } \\
\text { labium }\end{array}$ \\
\hline \multicolumn{6}{|l|}{ Pink } \\
\hline Unbanded & $12.25 \pm 0.12$ & $21.30 \pm 0.15$ & $0.55 \pm 0.02$ & $0.19 \pm 0.01$ & $0.17 \pm 0.02$ \\
\hline Mid-banded & $12.09 \pm 0.09$ & $21.18 \pm 0.11$ & $0.58 \pm 0.02$ & $0.20 \pm 0.01$ & $0.20 \pm 0.01$ \\
\hline Three-banded & $12.02 \pm 0.16$ & $20.87 \pm 0.20$ & $0.60 \pm 0.03$ & $0.19 \pm 0.01$ & $0.24 \pm 0.02$ \\
\hline Five-banded & $12.16 \pm 0.13$ & $21.00 \pm 0.17$ & $0.60 \pm 0.03$ & $0.20 \pm 0.01$ & $0.22 \pm 0.01$ \\
\hline \multicolumn{6}{|l|}{ Yellow } \\
\hline Unbanded & $12.18 \pm 0.12$ & $21.00 \pm 0.15$ & $0.55 \pm 0.02$ & $0.16 \pm 0.01$ & $0.19 \pm 0.02$ \\
\hline Mid-banded & $12.30 \pm 0.12$ & $21.37 \pm 0.16$ & $0.56 \pm 0.03$ & $0.20 \pm 0.01$ & $0.22 \pm 0.01$ \\
\hline Three-banded & $11.99 \pm 0.18$ & $20.34 \pm 0.23$ & $0.58 \pm 0.04$ & $0.21 \pm 0.02$ & $0.21 \pm 0.02$ \\
\hline Five-banded & $12.06 \pm 0.12$ & $21.23 \pm 0.15$ & $0.55 \pm 0.02$ & $0.15 \pm 0.01$ & $0.22 \pm 0.02$ \\
\hline
\end{tabular}


Table 2 Comparisons of shell features among the studied $C$. nemoralis morphs (ANOVA)
Groups labelled with the same lowercase letters $(a>b)$ in the last column did not differ from one another (post hoc Tukey test). Numbers $0-5$ refer to various banding types (unbanded, mid-banded, three-banded and five-banded, respectively)

${ }^{\text {a }}$ Significant effects

\begin{tabular}{llrlrll}
\hline Variable & Factor & df & \multicolumn{1}{l}{ MS } & \multicolumn{1}{l}{$F$} & $P$ value & Post hoc test \\
\hline Columella & Colour (C) & 1 & 0.000 & 0.00 & 0.9816 & \\
Height & Banding (B) & 3 & 0.410 & 0.86 & 0.4636 & \\
& C $\times$ B & 3 & 0.379 & 0.79 & 0.4987 & \\
Shell & Error & 252 & 0.478 & & & \\
Width & Colour (C) & 1 & 0.518 & 0.65 & 0.4223 & \\
& Banding (B) & 3 & 3.684 & 4.59 & $0.0038^{\mathrm{a}}$ & 0a 1a 3b 5a \\
& C $\times$ B & 3 & 1.825 & 2.28 & 0.0803 & \\
Shell & Error & 252 & 0.802 & & & \\
Mass & Colour (C) & 1 & 0.029 & 1.43 & 0.2328 & \\
& Banding (B) & 3 & 0.015 & 0.73 & 0.5321 & \\
Shell & C $\times$ B & 3 & 0.005 & 0.24 & 0.8671 & \\
Thickness & Error & 250 & 0.020 & & & \\
& Colour (C) & 1 & 0.001 & 0.42 & 0.5156 & \\
& Banding (B) & 3 & 0.011 & 4.43 & $0.0047^{\mathrm{a}}$ & 0b 1a 3a 5ab \\
& Breakage type (BT) & 1 & 0.026 & 10.22 & $0.0016^{\mathrm{a}}$ & Apex b Labium a \\
& C $\times$ B & 3 & 0.002 & 0.82 & 0.4853 & \\
& C $\times$ BT & 1 & 0.003 & 1.16 & 0.2831 & \\
& B $\times$ BT & 3 & 0.005 & 1.90 & 0.1298 & \\
& C $\times$ B $\times$ BT & 3 & 0.005 & 1.88 & 0.1327 & \\
& Error & 244 & 0.003 & & & \\
& & & & & &
\end{tabular}

Strength of external skeletons has been shown to be a principal anti-predator defence for molluscs. For example, European oystercatchers Haematopus ostralegus preferentially selected thin-shelled mussels Mytilus edulis (Durell et al. 1984; Nagarajan et al. 2002). Moreover, the increase in shell thickness is a known defence mechanism against shell-crushing predators in both aquatic and land snails (Lewis and Magnuson 1999; Allen 2004; Dalziel and Boulding 2005). However, only Quensen and Woodruff (1997) suggested that predator selectivity could be based on the shell strength of a land snail.

We have shown that shell strength of $C$. nemoralis strongly depended on shell thickness, which was also suggested for $C$. nemoralis by Jordaens et al. (2006) as well as for other gastropods, such as Littorina pallescens (Cook and Kenyon 1993) and Cerion sp. (Quensen and Woodruff 1997). We show that pink morphs have more resistant shells than yellow ones. Jordaens et al. (2006) did not find significant differences between these $C$. nemoralis morphs, perhaps due to the differences in shell areas subjected to measurements or techniques of breaking shells since shell thickness was similar in both studies. Moreover, Jordaens et al. (2006) did not consider banding pattern of studied morphs which may have contributed to the greater variation within their colour categories. In our study, darker (pink) morphs showed higher increment in shell strength with the increase in shell thickness than yellow individuals did, which may explain their greater resistance. Banded forms (particularly three-banded ones) also showed higher increase in shell strength with shell thickness than unbanded individuals. This relationship is independent of differences in absolute shell dimensions among morphs, demonstrating that the banding pattern in itself affects shell resistance. Dark bands are present in all shell layers (Emberton 1963). The crushing resistance of a molluscan shell depends mainly on its middle calcareous prismatic layer (Le Rossignol et al. 2011); thus, the strengthening role of the dark bands present in this layer is likely.
Table 3 Spearman correlation coefficients among the studied shell parameters

$* P<0.05, * * * P<0.001$

(statistically significant)

\begin{tabular}{|c|c|c|c|c|c|}
\hline & $\mathrm{H}$ & W & $\mathrm{Ta}$ & $\mathrm{Tl}$ & M \\
\hline \multicolumn{6}{|l|}{ Columella height $(\mathrm{H})$} \\
\hline Shell width (W) & $0.49 * * *$ & & & & \\
\hline Shell thickness at the apex (Ta) & $0.33 * * *$ & 0.12 & & & \\
\hline Shell thickness at the labium (Tl) & -0.04 & -0.10 & & & \\
\hline Shell mass (M) & $0.30 * * *$ & $0.19 *$ & $0.77 * * *$ & $0.72 * * *$ & \\
\hline Shell strength at the apex & $0.27 *$ & 0.12 & $0.72 * * *$ & & $0.79 * * *$ \\
\hline Shell strength at the labium & -0.09 & -0.16 & & $0.73 * * *$ & $0.61 * * *$ \\
\hline
\end{tabular}


Fig. 3 Mean shell strength $( \pm \mathrm{SE})$ of the studied morphs of C. nemoralis. Numbers of particular morphs used in the study are shown above the plot. Numbers $0-5$ below the bars indicate banding pattern: unbanded, mid-banded, threebanded and five-banded morphs, respectively. The banding types labelled with the same letters on the bars did not differ significantly from one another (within the same shell colour and area) $(\mathrm{a}>\mathrm{b}>\mathrm{c})$. Asterisks indicate banding types for which significant differences between shell areas (apex vs. labium) were observed. Sample sizes are given on the top of each bar

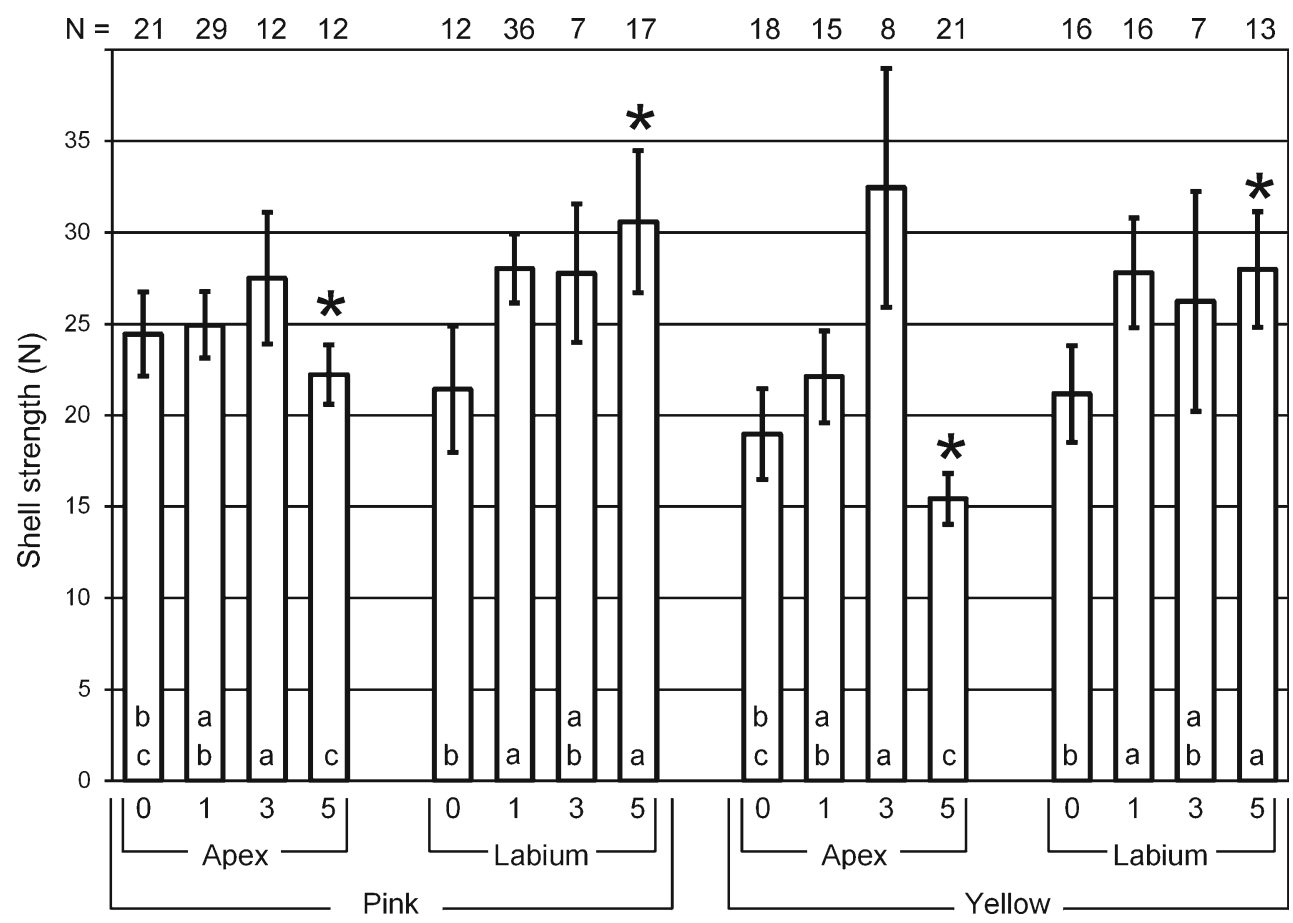

To our knowledge, there are no precise data on heritability of shell strength in snails. However, a study on marine gastropod Bembicum vittatum showed a strong genetic basis of its shell morphology (Parsons 1997) which is an important factor affecting shell strength (DeWitt 2000; Rundle and Brönmark 2001). On the other hand, shell strength could be strongly shaped by the environment, e.g. calcium availability. Nevertheless, as our snails were randomly collected and randomly distributed within one panmictic unit for this species (Lamotte 1951), the environmental impact on various morphs in our study was similar. Thus, we probably observed the genetic variability in shell strength among the morphs. However, our results should be treated with caution since we studied only one population and did not account for such factors as shell strength variation in different $C$. nemoralis colonies or across the lifespan of individuals. Nevertheless, we did demonstrate that a significant relationship between shell colour morph and strength can exist in $C$. nemoralis snails at least at a local scale.

The shell part usually attacked by birds (near the apex) was generally less resistant to crushing than that usually gnawed by mice (labium). Thrushes, specialising in consuming snails, hold a snail in their beak and hit it against an "anvil" (Morris 1954) trying to break various shell parts until
Table 4 General linear model of the effects of shell colour, shell banding pattern, breakage type (grouping variables), shell thickness (covariate) and their interactions on shell strength of $C$. nemoralis

${ }^{\mathrm{a}}$ Significant effects

\begin{tabular}{lrrrr}
\hline Variable & df & \multicolumn{1}{l}{ MS } & $F$ & $P$ value \\
\hline Colour (C) & 1 & 603.0 & 9.8 & $0.0020^{\mathrm{a}}$ \\
Banding (B) & 3 & 256.5 & 4.2 & $0.0068^{\mathrm{a}}$ \\
Shell area (SA) & 1 & 21.9 & 0.4 & 0.5524 \\
Thickness (T) & 1 & 13373.3 & 216.4 & $0.0000^{\mathrm{a}}$ \\
Interactions & & & & \\
$\mathrm{C} \times \mathrm{B}$ & 3 & 137.2 & 2.2 & 0.0866 \\
$\mathrm{C} \times \mathrm{SA}$ & 1 & 82.5 & 1.3 & 0.2490 \\
$\mathrm{~B} \times \mathrm{SA}$ & 3 & 359.9 & 5.8 & $0.0007^{\mathrm{a}}$ \\
$\mathrm{C} \times \mathrm{B} \times \mathrm{SA}$ & 3 & 768.8 & 0.4 & 0.7587 \\
$\mathrm{C} \times \mathrm{T}$ & 1 & 316.7 & 5.1 & $0.0005^{\mathrm{a}}$ \\
$\mathrm{B} \times \mathrm{T}$ & 3 & 16.4 & 0.3 & $0.0019^{\mathrm{a}}$ \\
$\mathrm{SA} \times \mathrm{T}$ & 1 & 61.8 & & 0.6074 \\
Error & 238 & &
\end{tabular}



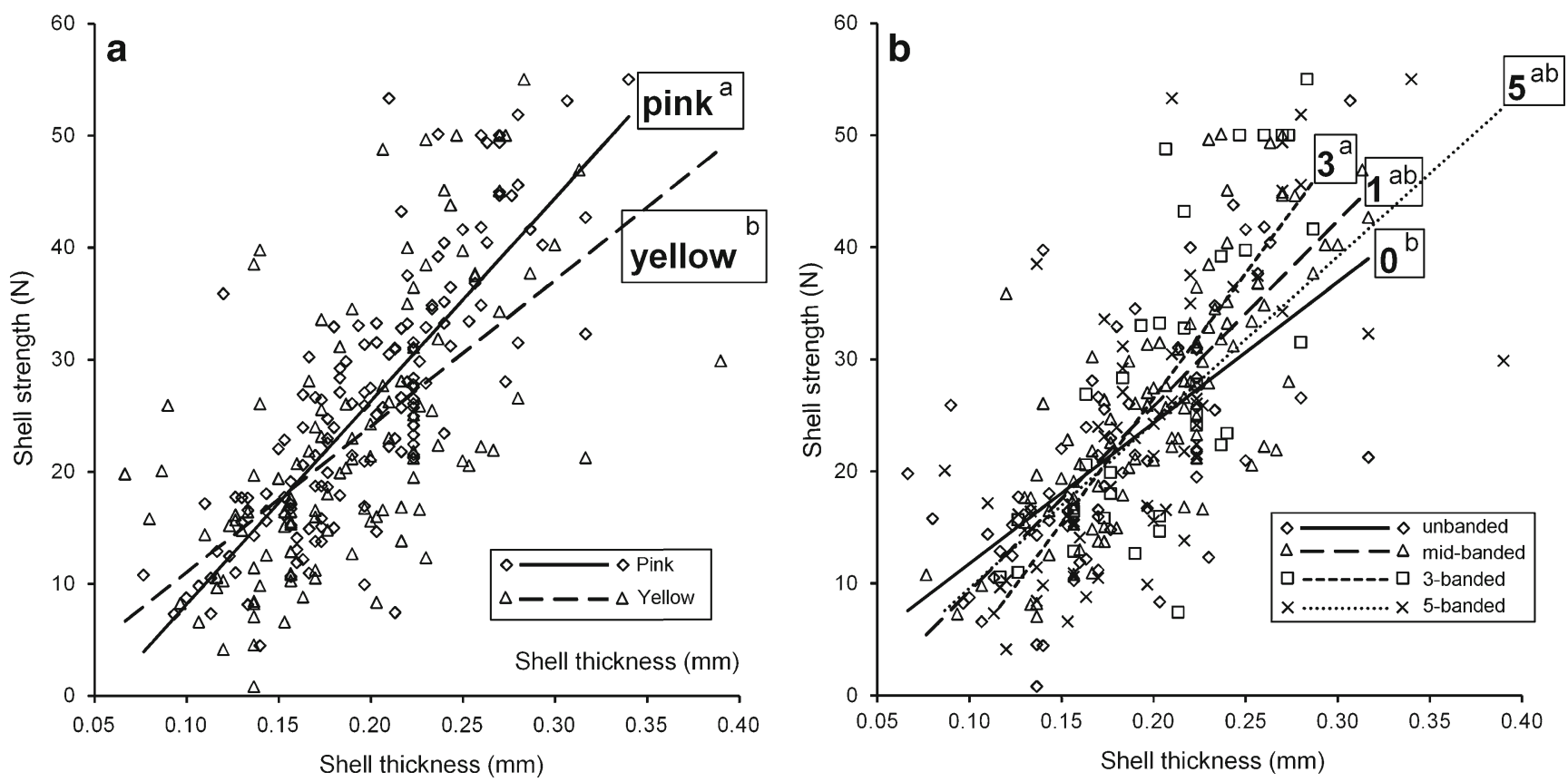

Fig. 4 Relationships between shell thickness and strength for various shell colours (a) and banding types (b) in C. nemoralis. The slopes of lines labelled with the same superscript letters did not differ significantly from one another $(a>b)$

they find the thinnest area. By contrast, mice, having relatively small jaws and mouth gape, can only access a shell at the aperture, so the strengthening of this area may help snails avoid mice predation.

In the study by Rosin et al. (2011) mice preyed most heavily on yellow unbanded and one-banded morphs, which in the present study had the weakest shell areas near the aperture. Mice use mainly olfactory stimuli in foraging (Allen 2004). Thus, their predation on snails is probably based on trial and error resulting in the highest feeding rate on snails with weak shells. This, together with the differences in shell strength among colour morphs found in the present study, could explain the selectivity of mice towards particular morphs observed by Rosin et al. (2011). Other factors than shell strength may affect mouse predation on Cepaea morphs, e.g. associations of morphs and mice to various (micro)habitats (Silvertown et al. 2011). Moreover, mouse predation may be different on juvenile snails (not studied). However, it is unlikely that any mouse selectivity based on juvenile shell strength occurs since juvenile shells are thinner and less resistant to breakage than adult shells (Jordaens et al. 2006) and usually are swallowed in whole. Nevertheless, mice belong to the most important predators hunting adult $C$. nemoralis (Allen 2004; Rosin et al. 2011) and almost $60 \%$ of colonies show traces of mouse predation on adult snails (Rosin's personal observation). On the other hand, birds, having greater abilities to crush shells and being visual predators, may depend mainly on morph conspicuousness (e.g. Cain and Sheppard 1954; Allen and Clarke 1968; Surmacki et al. 2013).
Many factors, including habitat heterogeneity, migration rate, landscape structure etc., might have also influenced the maintenance of shell polymorphism in Cepaea. The open question is how important the individual factors are. We consider predation as one of the factors that require more attention than it has been given to date in Cepaea. Many questions about ultimate and proximate factors shaping differential predator pressure on Cepaea morphs are unresolved. Our results suggest that shell crushing resistance may be a proximate factor of differential predatory pressure on Cepaea morphs, justifying future studies on the direct effect of variable shell strength of $C$. nemoralis morphs on predator selectivity.

Acknowledgments We thank Piotr Skórka, Zbigniew Kwieciński, Adrian Surmacki, Robert A. D. Cameron, Menno Schilthuizen and two anonymous referees for constructive discussions and comments on an early version of the manuscript. Z. M. Rosin was supported by a scholarship from the Adam Mickiewicz University Foundation in Poznań in 2012. This study was supported by a grant project from National Science Centre of Poland (no. 2011/N/NZ8/02015).

Open Access This article is distributed under the terms of the Creative Commons Attribution License which permits any use, distribution, and reproduction in any medium, provided the original author(s) and the source are credited.

\section{References}

Allen JA (2004) Avian and mammalian predators of terrestrial gastropods. In: Barker GM (ed) Natural enemies of terrestrial molluscs. CABI, New Zealand 
Allen JA, Clarke BC (1968) Evidence for apostatic selection by wild passerines. Nature 220:501-502

Allen JA, Weale ME (2005) Anti-apostatic selection by wild birds on quasi-natural morphs of the land snail Cepaea hortensis: a generalised linear mixed models approach. Oikos 108:335-343

Cain AJ, Currey JD (1963) Area effects in Cepaea. Philos Trans R Soc Lond B 246:1-81

Cain AJ, Sheppard PM (1950) Selection in the polymorphic land snail Cepaea nemoralis. Heredity 4:275-294

Cain AJ, Sheppard PM (1954) Natural selection in Cepaea. Genetics 39:89-116

Cain AJ, Sheppard PM, King JMB (1968) Studies on Cepaea. I. The genetics of some morphs and varieties of Cepaea nemoralis $\mathrm{L}$. Genetics 45:393-411

Cameron RAD, Cook LM (2012) Correlated phenotypic responses to habitat difference in Cepaea nemoralis (L.). Folia Malacol 20:255-263

Cameron RAD, Pokryszko BM (2008) Variation in Cepaea population over 42 years: climate fluctuations destroy a topographical relationship of morph frequencies. Biol J Linn Soc 95:53-61

Clarke BC (1962) Natural selection in mixed populations of two polymorphic snails. Heredity 17:319-345

Clarke BC (1969) The evidence for apostatic selection. Heredity 24:347-352

Cook LM (1986) Polymorphic snails on varied backgrounds. Biol J Linn Soc 29:89-99

Cook LM (1998) A two-stage model for Cepaea polymorphism. Phil Trans R Soc Lond B 353:1577-1593

Cook LM (2005) Disequilibrium in some Cepaea populations. Heredity 94:497-500

Cook LM, Kenyon G (1993) Shell strength of colour morphs of the mangrove snail Littorina pallescens. J Mollus Stud 59:29-34

Dalziel B, Boulding EG (2005) Water-borne cues from a shell-crushing predator induce a more massive shell in experimental populations of an intertidal snail. J Exp Mar Biol Ecol 317:25-35

DeWitt TJ (2000) Functional diversity among predators of a freshwater snail imposes an adaptive trade-off for shell morphology. Evol Ecol Res 2:129-148

Durell SEA, Le V, Dit G-CJD (1984) Prey selection within a size-class of mussels, Mytilus edulis, by oystercatchers, Haematopus ostralegus. Anim Behav 32:1197-1203

Emberton LRB (1963) Relationship between pigmentation of shell and mantle in the snails Cepaea nemoralis (L.) and Cepaea hortensis (mull.). Proc Zool Soc Lond 140:273-293

Gittenberger E (1996) Adaptations of the aperture in terrestrial gastropod-pulmonate shells. Neth J Zool 46:191-205

Hargeby A, Johansson J, Ahnesjo J (2004) Habitat-specific pigmentation in a freshwater isopod: adaptive evolution over a small spatiotemporal scale. Evolution 58:81-94

Hoekstra HE, Drumm KE, Nachman MW (2004) Ecological genetics of adaptive color polymorphism in pocket mice: geographic variation in selected and neutral genes. Evolution 58:1329-1341

Huelsken T (2011) First evidence of drilling predation by Conuber serdidus (Swainson, 1821) (Gastropoda: Naicidae) on soldier crabs (Crustacea: Mictyridae). Molluscan Res 31:125-132

Hutchison DW, Templeton AR (1999) Correlation of pairwise genetic and geographic distance measures: inferring the relative influences of gene flow and drift on the distribution of genetic variability. Evolution 53:1898-1914

Johannesson K, Ekendahl A (2002) Selective predation favouring cryptic individuals of marine snails (Littorina). Biol J Linn Soc 76:137-144

Jones JS (1974) Environmental selection in snail Cepaea vindobonensis in Lika area of Yugoslavia. Heredity 32:165-170

Jones JS, Leith BH, Rawlings P (1977) Polymorphism in Cepaea: a problem with too many solutions? Ann Rev Ecol Syst $8: 109-143$
Jordaens K, De Wolf H, Vandecasteele B, Blust R, Backeljau T (2006) Associations between shell strength, shell morphology and heavy metals in the land snail Cepaea nemoralis (Gastropoda, Helicidae). Sci Total Environ 363:285-293

Kitching JA, Lockwood J (1974) Observations on shell form and its ecological significance in thaisid gastropods of the genus Lepsiella in New Zeland. Mar Biol 28:131-144

Krist AC (2002) Crayfish induce a defensive shell shape in a freshwater snail. Invertebr Biol 121:235-242

Lamotte M (1951) Recherches sur la structure génétique des populations naturelles de Cepaea nemoralis (L.). Heredity $6: 333-343$

Lamotte M (1954) Sur le déterminisme génétique du polymorphisme chez Cepaea nemoralis. L C R Acad Sci (Paris) 239:365-367

Le Mitouard E, Bellido A, Guiller A, Madec L (2010) Spatial structure of shell polychromatism in Cepaea hortensis in relation to gradient of a landscape fragmentation in Western France. Landscape Ecol 25:123-134

Le Rossignol AP, Buckingham SG, Lea SEG, Nagarajan R (2011) Breaking down the mussel (Mytilus edulis) shell: which layers affect oystercatchers' (Haematopus ostralegus) prey selection? J Exp Mar Biol Ecol 405:87-92

Lewis DB, Magnuson JJ (1999) Intraspecific gastropod shell strength variation among north temperate lakes. Can J Fish Aquat Sci 56:1687-1695

Merilaita S (2001) Habitat heterogeneity, predation and gene flow: colour polymorphism in the isopod, Idotea baltica. Evol Ecol 15:103-116

Moreno-Rueda G (2009) Disruptive selection by predation offsets stabilizing selection on shell morphology in the land nasil Iberus g. gualtieranus. Evol Ecol 23:463-471

Morris D (1954) The snail-eating behaviour of thrushes and blackbirds. Brit Birds 47:33-48

Murray JJ (1975) The genetics of the Mollusca. In: King RC (ed) Handbook of genetics. Plenum, New York

Nagarajan R, Lea SEG, Goss-Custard JD (2002) Mussel valve discrimination and strategies used in valve discrimination by the oystercatcher, Haematopus ostralegus. Funct Ecol 16:339-345

Norris K, Johnstone I (1998) The functional response of oystercatchers (Haematopus ostralegus) searching for cockles (Cerastoderma edule) by touch. J Anim Ecol 67:329-346

Ożgo M (2008) Current problems in the research of Cepaea polymorphism. Folia Malacol 16:55-60

Ożgo M (2012) Shell polymorphism land-snail Cepaea nemoralis (L.) along a west-east transect in continental Europe. Folia Malacol 20:181-253

Parsons KE (1997) Contrasting patterns of heritable geographic variation in shell morphology and growth potential in the marine gastropod Bembicum vittatum: evidence from field experiments. Evolution 51:784-796

Pokryszko BM, Cameron RAD, Horsák M (2012) Variation in the shell colour and banding polymorphism of Cepaea nemoralis (L.) in rural areas around Wrocław. Folia Malacol 20:87-98

Punzalan D, Rodd FH, Hughes KA (2005) Perceptual processes and the maintenance of polymorphism through frequency-dependent predation. Evol Ecol 19:303-320

Quensen JF III, Woodruff DS (1997) Associations between shell morphology and land crab predation in the land snail Cerion. Funct Ecol 11:464-471

Reed WL, Janzen FJ (1999) Natural selection by avian predators on size and colour of a freshwater snail (Pomacea flagellata). Biol J Linn Soc 67:331-342

Richards AV, Murray JJ (1975) The relation of phenotype to habitat in an introduced colony of Cepaea nemoralis. Heredity 34:128-131

Rosenblum EB, Hoekstra HE, Nachman MW (2004) Adaptive reptile color variation and the evolution of the Mc1r gene. Evolution 58:1794-1808 
Rosin ZM, Olborska P, Surmacki A, Tryjanowski P (2011) Differences in predatory pressure on terrestrial snails by birds and mammals. $\mathrm{J}$ Bioscience 36:691-699

Rowland HM, Cuthill IC, Harvey IF, Speed MP, Ruxton GD (2008) Can't tell the caterpillars from the trees: countershading enhances survival in a woodland. Proc R Soc Lond B 275:2539-2545

Rundle SD, Brönmark C (2001) Inter- and intraspecific trait compensation of defense mechanisms in freshwater snails. Proc R Soc Lond B Biol Sci 268:1463-1468

Ruxton GD, Sherratt TN, Speed MP (2004) Avoiding attack: the evolutionary ecology of crypsis, warning signals and mimicry. Oxford University, New York

Sheppard PM (1951) Fluctuations in the selective value of certain phenotypes in the polymorphic land snail Cepaea nemoralis (L.). Heredity 5:125-134

Silvertown J, Cook L, Cameron R, Dodd M, McConway K et al (2011) Citizen science reveals unexpected continental-scale evolutionary change in a model organism. PLoS One 6:e18927
Smallegange IM, van der Meer J (2003) Why do shore crabs not prefer the most profitable mussels? J Anim Ecol 72:599-607

Sokal RR, Rohlf FJ (1995) Biometry, 3rd edn. W.H. Freeman \& Company, New York

Stephen DW, Krebs JR (1986) Foraging theory. Princeton University, Princeton

Surmacki A, Ożarowska A, Rosin ZM (2013) Color polymorphism in a land snail Cepea nemoralis (Pulmonata: Helicidae) as viewed by potential avian predators. Naturwissenschaften 100:533540

Svänback R, Eklöv P (2011) Catch me if you can-predation affects divergence in a polyphenic species. Evolution 65: $3515-3526$

Wiktor A (2004) Ślimaki lądowe Polski (Terrestrial gastropods of Poland). Mantis, Olsztyn

Wolda H (1963) Natural populations of the polymorphic land snail Cepaea nemoralis (L.). Factors affecting their size and their genetic constitution. Arch Néderl Zool 15:381-471 